\title{
Strain specificity in antimicrobial activity of non-thermal plasma
}

\author{
Hammad R. Humud ${ }^{1}$, Maha Adel Mahmood ${ }^{2}$, Wafaa Abd Al-Razaq ${ }^{1}$
}

\author{
${ }^{1}$ Department of Physics, College of Science, University of Baghdad \\ ${ }^{2}$ Department of Basic Science, College of Dentistry, Baghdad University \\ E-mail: dr.hammad6000@yahoo.com
}

\begin{abstract}
Non-thermal (low-temperature) plasma may act as an alternative approach to control superficial wound and skin infections when the effectiveness of chemical agents is weak due to natural pathogen or biofilm resistance. In this paper an atmospheric pressure plasma needle jet device which generates a cold plasma jet is used to measure the effectiveness of plasma treatment against different pathogenic bacteria and to test the individual susceptibility of pathogenic bacteria to non-thermal argon plasma. It is found that, Gram-negative bacteria were more susceptible to plasma treatment than Gram-positive bacteria. For the Gram-negative bacteria Pseudomonas aeruginosa, there were no survivors among the initial $1 \times 10^{8}$ C.F.U (Colony Forming Unit) after a 40 seconds plasma treatment. The susceptibility of Gram-positive bacteria and the Gram-negative bacteria were species and strain specific. Staphylococcus aureus was the most resistant with $4.5 \%$ survival of the initial $2 \times 10^{6}$ C.F.U. after a 40 seconds plasma treatment. According to species, Staphylococcus aureus had a strain-dependent resistance with 39\% and 99\% reduction from $2 \times 10^{6}$ C.F.U.of the five studied isolates, respectively, whereas, Escherichia coli had a lower resistance with $76 \%$ and $99 \%$ reduction after 40 seconds.

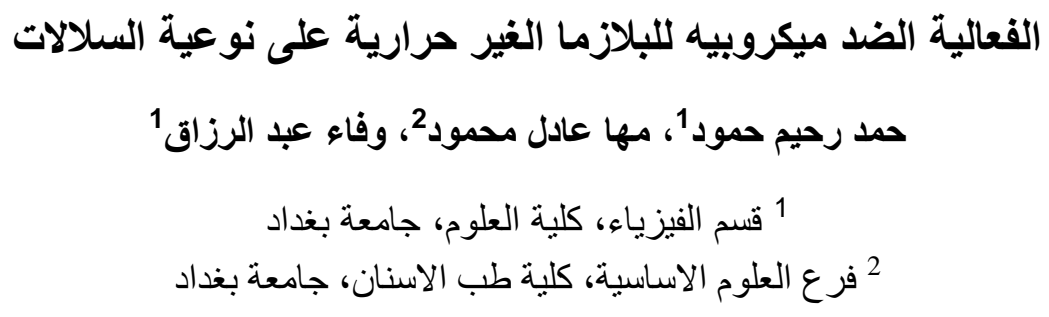
Key words Non-thermal plasma, needle plasma, bacteria deactivation plasma.

\author{
Article info \\ Received: Jan. 2013 \\ Accepted: Mar. 2013 \\ Published: Apr. 2013
}

الخلاصة

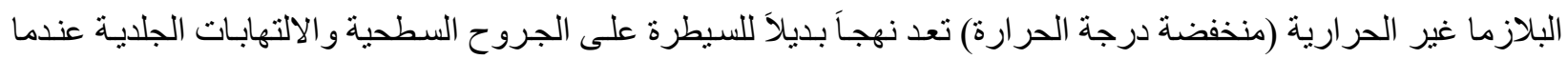

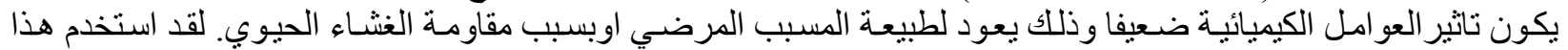

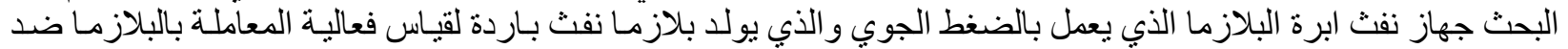

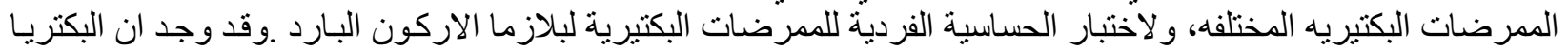

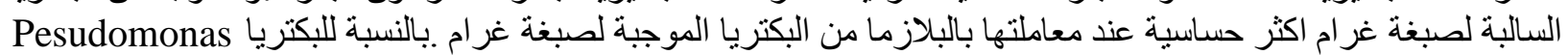
بعa aeraginosa

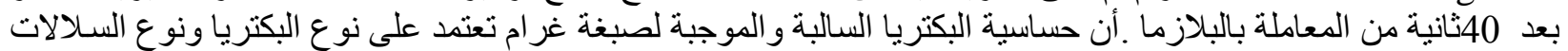

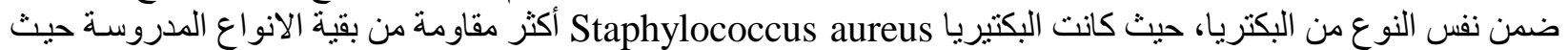

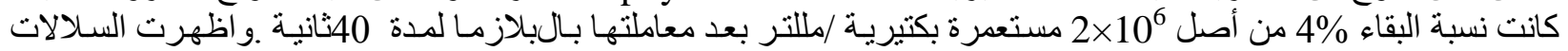

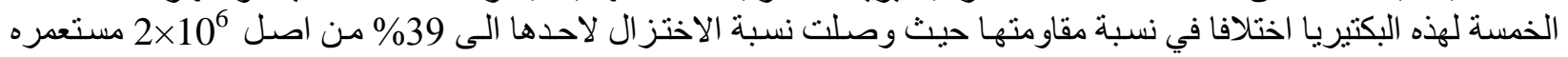
بكتيرية /مللتر بينما اظهرت بكتيريا Escherichia coli مقاومة اقل وصلت الى 76\% م لاحد السلالات المدروسة. 


\section{Introduction}

Opportunistic bacterial pathogens are ubiquitous inhabitants of both the environment and the human body, causing serious infections in immune compromised patients [1]. To fight opportunistic infections, most studies have focused on finding chemical bactericidal agents. Application of physical treatments presents an alternative approach when the effectiveness of chemical agents is weak due to natural pathogen or biofilm resistance. One physical treatment with a microbicidal action is non-thermal (low-temperature) physical plasma [2, 3, 4 ].

The plasma state can be considered to be a gaseous mixture of oppositely-charged particles with a roughly zero net electrical charge [5]. Besides charged particles, plasmas also contain neutral atoms and molecules, excited atoms and molecules, radicals and UV photons [6].

The most important active species in atmospheric plasma are the radicals; the role of UV is less pronounced because most of UV radiation produced re-absorbed in plasma [7].

Plasma needle may be used for fine tissue treatment (e.g., controlled cell removal without inflammation) and also for bacterial decontamination [7]. Possible uses of plasma needle include-among others-very rapid and gentle tissue disinfection via inactivation of diverse pathogens (Grampositive and Gram -negative bacteria, fungi, viruses, spores and parasites), precise tissue removal and stimulation of wound healing [8]. Furthermore, plasmas can modify surfaces for biomedical purposes, e.g., cell adhesion or biocompatibility [9].

Atmospheric glow discharges produce shortlived chemical species, which are propelled by the low-temperature gas toward a surface that is to be treated. The short life of these species is desirable because they do not remain after the treatment is completed [10]. A great advantage of non-thermal plasma treatment that are allergic or toxic reactions are not expected, painless, self-sterilizing, non-invasive application that allows for the treatment of heat-sensitive, in homogeneous surfaces and even live tissue [11].This characteristic opened up the possibility to use these plasmas for the treatment of heatsensitive materials including biological matter such as cells and tissues [12,13].

The purpose of this work was to measure the effectiveness of plasma treatment against bacteria, and to test the individual susceptibility of the pathogenic bacteria to non- thermal argon plasma.

\section{Experimental Work \\ 1. Setup}

Non-equilibrium plasma generated by a plasma needle was used for the treatment of bacteria. The plasma torch (shown in Fig. 1) is consisting from 10cc glass syringe adapted to a hallow stainless steel needle with inner diameter $1.04 \mathrm{~mm}$ from one side and the working gas (Ar) into other side through Teflon gas fitting. The needle is powered by high voltage of sinusoidal shape of $7.5 \mathrm{kV}$ and frequency of $28 \mathrm{kHz}$ peak to peak generated by high voltage transformer. The Ar gas is directed to the needle through the syringe and mixes with ambient air around the tip of the needle. The Ar gas was flowing at 1slm (standard liters per minute) flow rate through the needle. The jet length depends on argon gas flow rate and it can reach $3.5 \mathrm{~cm}$ in air at gas flow rate $1 \mathrm{slm}$. 


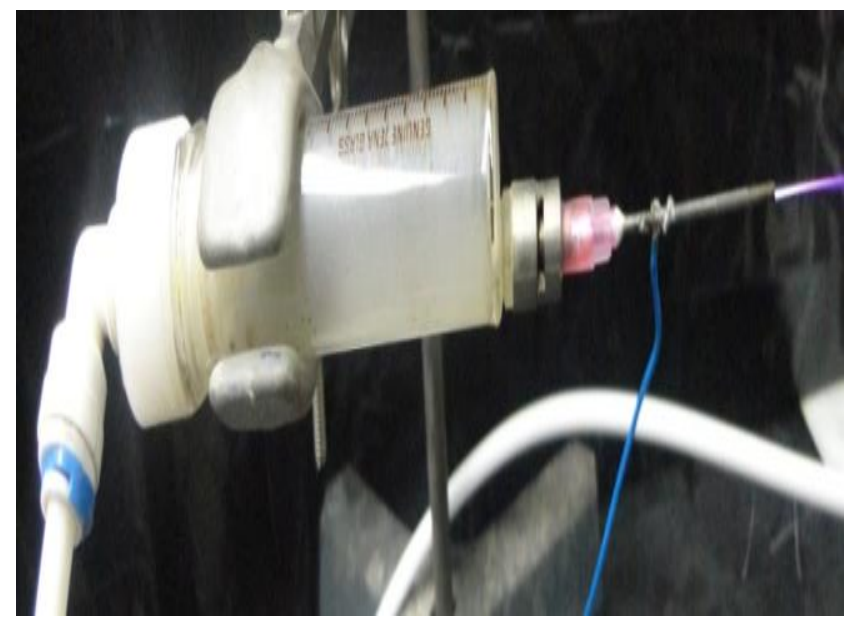

Fig.1: Plasma needle torch [14]

\section{Bacterial Sample Preparation}

The susceptibility of seven bacterial species of Gram-negative and Gram-positive like: Staphylococcus aureus, Enterococcus faecalis, Escherichia coli, P. aeruginosa, Proteus, Acinetobacter and Enterobacter and also five isolates of Staphylococcus aureus and five isolates of Escherichia coli, which were obtained from Al-Yarmook Teaching Hospital and Central Teaching laboratories, were tested. Several colonies were picked up from an overnight culture of each isolate, suspended into $3 \mathrm{ml}$ of Brain Heart Infusion broth (BHI), and then kept for $24 \mathrm{~h}$ at $37^{\circ} \mathrm{C}$. After $24 \mathrm{~h}$ of incubation, bacterial suspension (inoculum) was diluted with sterile physiological solution to $10^{8} \mathrm{CFU} / \mathrm{ml}$ was compared with 0.5 McFarland standard tubes.

\section{Sample Treatment by Plasma Needle}

For plasma treatment, liquate of 180 $\mu 1$ from each bacterial suspension were placed into a 96 wells microtiter plate at 6 $\mathrm{mm}$ distance from the needle tip. At this distance, the heating effect of substrate was minimized, while the irradiance could be sufficiently high.

Bacteria were treated with plasma at argon gas flow rate of $1 \mathrm{l} / \mathrm{min}$, Fig. 2 . The bacterial samples were treated by varying time between 40 and 120 seconds. For every treatment set, two types of control were used: completely untreated samples and samples treated only by the flow of the argon buffer gas but without plasma ignition [7].

After treatment completed in each well, tenfold dilutions of the bacterial suspension in saline solution were plated on blood agar plates. The plates were incubated at $37^{\circ} \mathrm{Cfor}$ $48 \mathrm{~h}$ and bacterial colonies were counted. The effectiveness of the treatment was calculated by two values, the first one by the calculation of the percentage of C.F.U. observed on agar for treated wells relative to C.F.U. for untreated wells at the lowest dilution where survival was observed [15]. All experiments were repeated at least three times [7].

The efficiency of the antimicrobial treatment is determined by comparing the reduction in bacterial concentration of the treated sample with that of control sample expressed as percentage reduction in standard time. Percentage reduction (R) was calculated using the following formula [16].

$R=\frac{N_{\mathrm{o}}-N_{t}}{N_{\mathrm{o}}} \times 100 \%$

where, $N_{0}$ is the number of bacteria in the broth inoculated with treated test sample immediately after inoculation i.e., at zero contact time and $N_{t}$ is the number of bacteria recovered from the both inoculated with treated test sample after the desired contact period, $t$ is the time of treatment.

The second calculated value is the "D" value (decimal value), the D-value is the time required to reduce an original concentration of microorganisms by $90 \%$ (or the time for a one $\log 10$ reduction). It can be expressed as follows[17].

$\mathrm{D}=\mathrm{t} /\left(\log \mathrm{N}_{0}-\log \mathrm{N}_{\mathrm{s}}\right)$ 
where $\mathrm{t}$ is the time to destroy $90 \%$ of the initial population, $\mathrm{N}_{0}$ is the initial population, and $\mathrm{N}_{\mathrm{s}}$ are the surviving population.

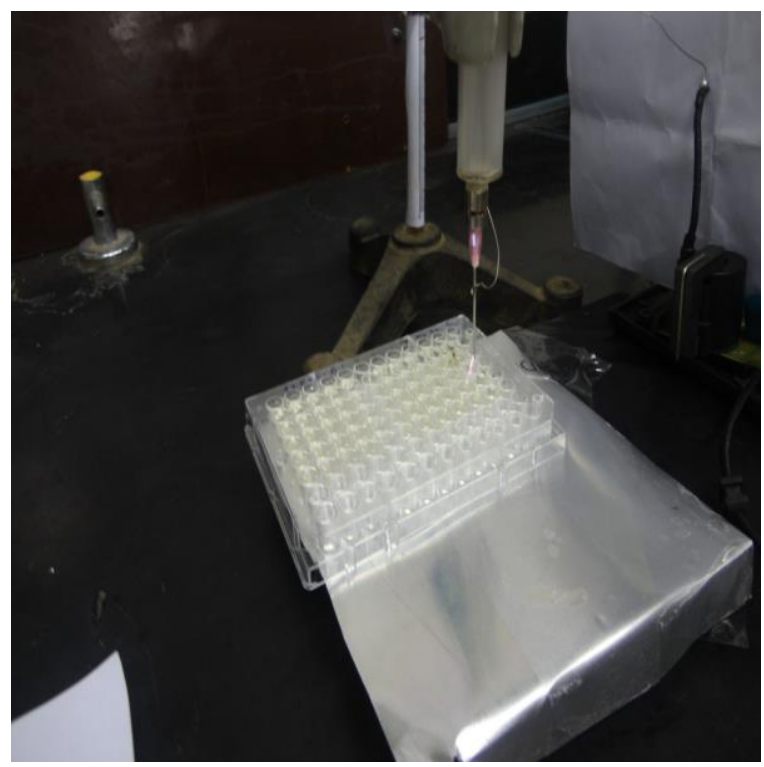

Fig.2: Experimental setup for bacterial treatment

\section{Results and Discussion}

The initial study compared the individual susceptibility of seven micro-organisms belonging to different species that are the most frequent causative agents of nosocomial and wound infections and the individual susceptibility of five isolates belong to Staphylococcus aureus and five isolates belong to Escherichia coli.

Table 1 shows the effect of plasma exposure on seven different bacterial isolates (S. aureus, E. faecalis, E. coli, Pseudomonas, Proteus, Acinetobacter and Enterobacter), which are treated by argon plasma for 40 seconds. There is a clear significant statistical differences $\mathrm{p}<0.05$ in the percentages of bacterial reduction among the different types of bacteria species and this may due to the differences in components of the cell wall of the Gram- positive bacteria and Gram- negative bacteria.
The majority of the tested isolates of the Gram-negative bacteria P. aeruginosa, Escherichia coli, Proteus and Acinetobacter had nearly similar susceptibility to the argon plasma as the observed reduction percentages was between $99 \%$ and $93 \%$ for different species after a 40 seconds treatment $(\mathrm{P}<0.05)$. There were no survivors' P. aeruginosa from the initial $10^{8}$ C.F.U. after a 40 seconds treatment.

Table1: Survival (s) and Reduction percentages of seven bacterial species

\begin{tabular}{|c|c|c|}
\hline Bacterial species & S\% & \% Reduction \\
\hline S. aureus & 4.5 & 0.954545 \\
\hline E. faecalis & 0.95 & 0.994048 \\
\hline E. coli & 6.8 & 0.932 \\
\hline Pseudomonas & 0.95 & 0.990435 \\
\hline Proteus & 1 & 0.985833 \\
\hline Acinetobacter & 2 & 0.975714 \\
\hline Enterobacter & 25 & 0.75 \\
\hline
\end{tabular}

Table 2 and 3 explain the antibacterial effect of plasma jet for three different times 40,80 and 120 s on ten different isolates using five isolates of $\mathrm{S}$. aureus (Grampositive bacteria) and five isolates of $\mathrm{E}$. coli (Gram- negative bacteria) to determine if there was a strain specificity in resistance of plasma. A statistical differences $\mathrm{p}<0.01$ were observed in killing percentages (reduction in C.F.U ) among the five isolates of S. aureus which ranged between $39 \%$ and 99\% when exposed to plasma flame jet at three specific periods of time 40, 80 and120s respectively. Indeed, there is an observed difference in percentages of bacterial reduction between the different isolates of the E. coli (Gram- negative bacteria). 
Table 2: The effect of plasma treatment time on different bacterial isolates

\begin{tabular}{|c|c|c|c|}
\hline Organism & $\begin{array}{c}\text { \% } \\
\text { Reduction } \\
\text { after 40s }\end{array}$ & $\begin{array}{c}\% \\
\text { Reduction } \\
\text { after 80s }\end{array}$ & $\begin{array}{c}\text { \% } \\
\text { Reduction } \\
\text { after 120s }\end{array}$ \\
\hline S. aureus1 & 0.9858 & 0.9898 & 0.992 \\
\hline S. aureus2 & 0.87 & 0.89 & 0.9 \\
\hline S. aureus3 & 0.903636 & 0.98364 & 0.989455 \\
\hline S. aureus4 & 0.393939 & 0.45455 & 0.69697 \\
\hline S. aureus5 & 0.4 & 0.935 & 0.9815 \\
\hline E. coli 1 & 0.9125 & 0.94 & 0.975 \\
\hline E. coli 2 & 0.766667 & 0.99 & 0.998333 \\
\hline E. coli 3 & 0.903226 & 0.97355 & 0.99929 \\
\hline E. coli 4 & 0.93 & 0.946 & 0.97 \\
\hline E. coli 5 & 0.926087 & 0.97174 & 0.981957 \\
\hline
\end{tabular}

The sensitivity of both $\mathrm{S}$. aureus isolates and E. coli isolates were increased successively with an increase in plasma exposure time from $40 \mathrm{~s}$ to $120 \mathrm{~s}$. Some isolates were sensitive and they were completely killed at 80s, while others were more resistant and complete killing occur after 120s. In contrast, some isolates would require a prolonged time to achieve complete sterilization.

Table 3: Survival and D-value of ten different bacterial isolates

\begin{tabular}{|l|l|l|l|l|}
\hline Organism & $\begin{array}{c}\text { S\% } \\
\text { after } \\
\text { 40s }\end{array}$ & $\begin{array}{c}\text { S\% } \\
\text { after } \\
\mathbf{8 0 s}\end{array}$ & $\begin{array}{c}\text { S\% } \\
\text { after } \\
\mathbf{1 2 0 s}\end{array}$ & D-value \\
\hline S. aureus1 & 1.42 & 1.02 & 0.8 & 40 \\
\hline S. aureus2 & 13 & 11 & 10 & 120 \\
\hline S. aureus3 & 9.63 & 1.63 & 1.05 & 40 \\
\hline S. aureus4 & 60.6 & 54.54 & 30.3 & $>120$ \\
\hline S. aureus5 & 60 & 6.5 & 1.85 & 80 \\
\hline E. coli 1 & 8.75 & 6 & 2.5 & 40 \\
\hline E. coli 2 & 3.33 & 1 & 0.16 & 40 \\
\hline E. coli 3 & 9.67 & 2.64 & 0.07 & 40 \\
\hline E. coli 4 & 7 & 5.4 & 3 & 40 \\
\hline E. coli 5 & 7.39 & 2.82 & 1.8 & 40 \\
\hline
\end{tabular}

The susceptibility of Gram-positive bacteria and Gram-negative bacteria were species and strain dependent. Staphylococcus aureus 1 clinical isolate was almost as sensitive as the Gram-negative bacteria; there were less than $2 \%$ survivors of the initial $10^{5}$ bacteria after a 40 seconds treatment. Staphylococcus aureus 4 clinical isolate and Staphylococcus aureus 2 clinical isolate had the lowest responsiveness. As approximately $30 \%$ and $10 \%$ respectively, survived a 120 seconds treatment, with only $0-3 \%$ of Escherichia coli forming colonies showed after a 120 seconds treatment $(\mathrm{P}<0.05)$, while no bactericidal effect was observed with the non-ionized argon gas.

According to the antibacterial activity, the present data proved that there were significant statistical differences $(p<0.01)$ in reduction percentages among different isolates that belonged to one species and this fact is true for Gram-positive and for Gramnegative bacteria which revealed the strain specificity in this matter.

Additionally, the present work showed no significant differences in killing percentage (redaction \%) for almost all of the studied isolates when the times of killing increased from 40 seconds to 120 seconds. This mean those 40 seconds is sufficient to get a good killing percent.

The results obtained show that, in general, non-thermal argon plasma needle is more effective against Gram-negative than Grampositive bacteria. The differences in cellwall structure can be critical for the differential sensitivity of Gram-negative and Gram-positive bacteria. Argon plasma acts via a complicated mechanism that includes a synergetic action of reactive species of different kinds, including ionized argon gas molecules, $\mathrm{O}_{\mathrm{x}}$ and $\mathrm{NO}_{\mathrm{x}}$ and UV light [18]. Plasma reactive particles produce a general mechanical effect on the surface of living organisms, which has been called etching [19].

In contrast, the existence of highly sensitive and resistant strains belonging to the Grampositive species Staphylococcus aureus, seen in the course of this study, it may due to differences in membrane lipid and/or protein composition among those bacteria [15]. 
The charge particles found in plasma play a very significant role in the rapture of the outer membrane of the bacterial cells. The electrostatic force caused by charge accumulation on the outer surface of the cell membrane could overcome the tensile strength of the membrane and cause its rupture. The electrostatic force is proportional to the square of the charging potential to the square of the radius of the curvature of the surface. The Gram-negative bacteria membrane has an irregular surface. These irregularities offer small radii of curvature that cause localized high electrostatic forces [16].

\section{Conclusions}

1) Plasma needle effective tool to treat different bacteria types.

2) There is a clear significant difference in the percentage of bacterial reduction among the different types of bacteria species.

3) The susceptibility of Gram-positive bacteria and Gram-negative bacteria were species and strain dependent.

4) The 40sec plasma bacteria treatment is sufficient to good killing percent.

5) Non-thermal argon plasma needle is more effective against Gram-negative than Grampositive bacteria.

6) The Staphylococcus aureus isolates has the lowest susceptibility to plasma needle.

\section{References}

[1] I.Brook, E. H. Frazier, Am J Emerg Med, 16 (1998) 585-591.

[2] M. M.Kayes, F. J.Critzer, K. KellyWintenberg, J.R. Roth, T.C. Montie, D.A.Golden, Foodborne Pathog Dis, 4 (2007) 50-59.

[3]K.Lee, K., Paek, W. Ju, Y. Lee,. J Microbiol, 44 (2006) 269-275.

[4] R. A Venezia, M. Orrico, E. Houston, S. Yin, Y.Y.Naumova, Infect Control Hosp Epidemiol, 29 (2008) 430-436.
[5] F. S. Denes, S. Manolache, Progress in Polymer Science, 29 (2004) 815-885.

[6]R. Morent and N. De Geyter. Inactivation of Bacteria by Non-Thermal Plasmas, Biomedical Engineering- Frontiers and Challenges, Prof. Reza Fazel (Ed.), ISBN: 978-953-307-309-5, 2011, InTech.

[7] E.A.Sosnin, E. Stoffels, M.V. Erofeev, I.E. Kieft, and S.E. Kunts, IEEE Trans. Plasma Sci., 32(2004)1544-1550.

[8]G. Morfill, M.G.Kong,J.L. Zimmermann, New Journal of Physics, 1 (2009). 115011.

[9]K. Schröder, A. Meyer-Plath, D. Keller, W. Besch, G. Babucke, and A. Ohl, Contrib. Plasma Phys., 41, 6 (Nov.2001) 562-572.

[10] J. Goree, B. Liu, D. Drake and E. Stoffels, IEEE Trans. Plasma Sci., 34, 4 (Aug. 2006) 1317-1324.

[11] A. Fridman, A. Chirokov, A..JPhys D: Applied Physics, 38 (2005) R1-R24.

[12] M. Laroussi, Plasma Process. Polym., 2, 5 (Jun. 2005) 391-400,.

[13] E. Stoffels, High Temp. Mater. Process, 6, 2 (2002) 191-202.

[14] Hammed R.Humud ,AhamadS.wasfi, WafaaAbd Al razaq, MazinS.El.Ansary : Iraqi Journal of Physics, 10, 17 (May 2012) 53-57.

[15]S.A.Ermolaeva, A.F.Varfolomeev, M.Y. Chernnukha, D.S.Yorov, M.M. Vasiliev, J. Med. Microbiol, 60, 1 (2011) 75-83.

[16] Shaymaa Saadoon Hashim "Design an atmospheric pressure non thermal plasma device for killing bacteria" Thesis submitted to the college of Science for Women, University of Baghdad, 2012.

[17] U. Kogelschatz, IEEE Trans. Plasma Sci., 30, 4 (Aug.2002) 1400-1408.

[18] T. Shimizu, B. Steffes, R. Pompl, F. Jamitzky, W. Bunk, K.Ramrath, M. Georgi, W.Stolz, H. Schmidt, Plasma Process Polym, 5 (2008) 577-582.

[19]M. Moreau, N.Orange, \& M.G. Feuilloley, Biotechnol Adv., 26 (2008) 610617. 